$\begin{array}{r}\text { Phinisi Integration Review } \\ \text { Vol. 3, No.2, Agustus 2020 Hal 305-315 } \\ \text { Website: } \text { http://ojs.unm.ac.id/pir } \\ \text { p-ISSN: 2614-2325 dan e-ISSN: 2614-2317 } \\ \text { DOI: https://doi.org/10.26858/v3i2.14971 } \\ \hline\end{array}$

\title{
Implementasi Program Penguatan Pendidikan Karakter Di Sekolah
}

\author{
Muhammad Zul Ahmadi ${ }^{1}$, Hasnawi Haris ${ }^{2}$, Muhammad Akbal $^{3}$ \\ ${ }^{1}$ Ilmu Pendidikan Sosial, SMPN 3 Bontomrannu, Indonesia \\ ${ }^{23}$ Ilmu Pendidikan Sosial, Universitas Negeri Makassar, Indonesia \\ Email: ${ }^{1}$ zulahmadi937@gmail.com
}

\begin{abstract}
Abstrak. Implementasi Program Penguatan Pendidikan Karakter Di SMPN 3 Bontomarannu Kabupaten Gowa. Penelitian ini bertujuanuntuk mengetahui: (i)implementasi program penguatan pendidikan karakter di SMPN 3 Bontomarannu Kabupaten Gowa;(ii) faktor pendukung dalam implementasi program penguatan pendidikan karakter di SMPN 3 Bontomarannu Kabupaten Gowa;dan (iii) faktor penghambat dalam implementasi program penguatan pendidikan karakter di SMPN 3 Bontomarannu Kabupaten Gowa.Penelitian menggunakanjenis penelitiankualitatif dengan pendekatan deskriptif.Berdasarkansumbernya,jenis data yang digunakan yaitu data primer dan sekunder. Data primer diperoleh melalui metode wawancara terhadap guru dan siswa serta dokumentasi dan observasi. Sedangkan data sekunder yaitu data yang diperoleh dari berbagai literatur seperti buku, undang-undang maupun sumber lain yang berkaitan. Pengolahan dan penyajian data dilakukan secara deskriptif.Hasilpenelitian menunjukkan bahwa: (i)Implementasi Penguatan Pendidikan Karakter di SMPN 3 Bontomarannu sudah berjalan namun pelaksanaannya belum maksimal. (ii) Faktor pendukung dalam mengimplementasikan penguatan pendidikan karakter di SMPN 3 Bontomarannu adalah adanya kompetensi guru, kerjasama yang baik dari wali peserta didik, kurikulum sekolah yang sudah baik, serta pengawasan intens dari kepala sekolah. (iii) Faktor penghambat dalam mengimplementasikan penguatan pendidikan karakter di SMPN 3 Bontomarannu adalah sarana dan prasarana, kualifikasi akademik guru yang tidak sesuai dengan mata pelajaran yang diajarkan, adanya karakter yang berbeda-beda pada peserta didik serta kedisiplinan peserta didik yang masih rendah.
\end{abstract}

Kata Kunci: Implementasi, Penguatan Pendidikan Karakter

Abstract.Implementation of the Character Building Strengthening Program at SMPN 3 Bontomarannu, Gowa Regency. This study aims to determine: (i) the implementation of a program to strengthen character education at SMPN 3 Bontomarannu, Gowa Regency; (ii) supporting factors in implementing the character education strengthening program at SMPN 3 Bontomarannu, Gowa Regency; and (iii) inhibiting factors in implementing character education strengthening programs at SMPN 3 Bontomarannu, Gowa Regency. The study uses qualitative research with a descriptive approach. Based on the source, the type of data used is primary and secondary data. Primary data obtained through interviews with teachers and students as well as documentation and observation. While secondary data is data obtained from various literatures such as books, laws and other related sources. Data processing and presentation are done descriptively. The results showed that: (i) Implementation of Strengthening Character Education at SMPN 3 Bontomarannu was already running but its implementation was not yet optimal. (ii) Supporting factors in implementing the strengthening of character education in SMPN 3 Bontomarannu are the existence of teacher competence, good cooperation from students' guardians, good school curriculum, and intense supervision from the school principal. 
(iii) The inhibiting factors in implementing the strengthening of character education in Bontomarannu 3 Public Middle School are facilities and infrastructure, academic qualifications of teachers that are not in accordance with the subjects taught, there are different characters in students and the discipline of students is still low.

Keywords: Implementation, Strengthening Character Education

Ini adalah artikel dengan akses terbuka dibawah licenci CC BY-NC-4.0

(https://creativecommons.org/licenses/by-nc/4.0/).

\section{PENDAHULUAN}

Pendidikan sebagai upaya dalam menumbuh kembangkan pengetahuan, karakter dan keterampilan peserta didik agar menjadi generasi muda yang siap dan mampu menghadapi segala tantangan yang menyangkut perubahan sosial dalam kehidupan masyarakat. Kemajuan suatu bangsa terletak pada karakter yang dimiliki suatu bangsa, karakter merupakan hal yang penting dan mendasar. Tidak heran bila pendidikan bukan sekedar bertujuan untuk mengembangkan potensi pengetahuan dan keterampilan peserta didik dalam setiap proses pembelajaran, melainkan juga harus menanamkan nilai-nilai karakter yang baik dalam mengarungi kehidupan yang semakin maju.Membentuk karakter yang baik memang harus dilakukan sejak usia dini. Sudah menjadi prioritas lembaga pendidikan dalam pembentukan nilai-nilai karakter peserta didik sehingga agar anak tersebut mampu berguna bagi bangsa dan negara kedepannya.

Sekolah sebagai lembaga pendidikan tidak hanya bertujuan mencerdaskan siswa namun juga memiliki adab budi pekerti, sopan santun dan jiwa nasionalisme yang tinggi. Sekolah sebagai dari fungsi pendidikan nasional melalui fungsi sebagaimana dalam pasal 3 Undang-Undang Nomor 20 tahun 2003 tentang Sistem Pendidikan Nasional:Pendidikan Nasional berfungsi mengembangkan kemampuan dan membentuk watak serta peradaban yang bermartabat dalam rangka mencerdaskan kehidupan bangsa, bertujuan untuk perkembangannya potensi peserta didik agar menjadi manusia yang beriman dan bertakwa kepada tuhan yang maha esa, berakhlak mulia, sehat, berilmu, cakap, kreatif, mandiri dan menjadi warga negara yang demokratis serta bertanggung jawab.

Dalam fungsi pendidikan nasional tersebut terdapat beberapa nilai-nilai penting dalam pendidikan karakter yang perlu diterapkan untuk melaksanakan fungsi pendidikan nasional, maka dalam pelaksanaannya pendidikan karakter memerlukan peneladanan dan pembiasaan, dan diselenggarakan dengan memberdayakan semua komponen masyarakat melalui peran serta dalam penyelenggaraan penguatan karakter dan pengedalian mutu layanan pendidikan.

Berlangsungnya revolusi industri keempat yang ditandai dengan fenomena kemajuan teknologi informasi dan komunikasi dalam era revolusi digital. Perubahan peradaban masyarakat yang ditandai dengan sendi-sendi kehidupan, kebudayaan, peradaban dan kemasyarakatan termasuk pendidikan. Hal tersebut telah memunculkan tatanan baru, ukuran-ukuran baru, dan kebutuhan-kebutuhan baru yang berbeda dengan sebelumnya, yang harus ditanggapi dan dipenuhi oleh seluruh pemangku kepentingan pendidikan. Disinilah letak peran sentral dari dunia pendidikan untuk menyiapkan Sumber Daya Manusia (SDM) sebagai kapital intelektual yang mampu beradaptasi dan diharapkan memiliki keunggulan kompetitif di dalam era persaingan global.Para pemangku kepentingan pendidikan terus berupaya dalam menekankan pentingnya nilai dan karakter yang harus dimiliki oleh individu di keberlangsungan era revolusi industri keempat. Dengan demikian maka mulai dirumuskan dan dikembangkan bentuk-bentuk pendidikan yang relevan di era revolusi industri keempat. Banyak perubahan yang terjadi diantaranya adalah perubahan paradigma hasil belajar menjadi tiga aspek yaitu pengetahuan, keterampilan dan sikap. Serta yang paling penting saat ini adalah bagaimana mengembangkan karakater yang semakin terkikis saat ini untuk menyeimbangi teknologi yang kian berkembang pesat untuk menjadikan sumber daya manusia indonesia yang unggul dan tetap berpengan pada nilai-nilai pancasila. Indonesia telah berupaya menyempurnakan sistem pendidikan, dengan 
selalu memperbaharui berbagai kebijakan dan perundang-undangan sistem pendidikan nasional. Hal itu dilakukan agar pendidikan benar-benar mampu menjadi agen pembaharuan dan kemajuan bagi bangsa dan negaranya dengan tetap berlandaskan pada prinsip nilainilai Pancasila.

Penguatan pendidikan karakter merupakan upaya untuk menumbuhkan dan membekali generasi penerus agar memiliki bekal karakter baik, keterampilan literasi yang tinggi, dan memiliki kompetensi unggul di era revolusi industri keempat yaitu mampu berpikir kritis dan analitis, kreatif, komunikatif, dan kolaboratif.Upaya pembentukan karakter diperkuat dengan adanya Permendikbud No. 20 Tahun 2018 tentang Penguatan Pendidikan Karakter. Dalam Permendikbud tersebut ditegaskan bahwa Penguatan Pendidikan Karakter yang selanjutnya disingkat PPK merupakan gerakan pendidikan sekolah untuk memperkuat karakter peserta didik melalui harmonisasi olah hati, olah rasa, olah pikir dan olaraga. Dengan dukungan penglibatan publik dan kerjasama antar sekolah, keluarga, dan masyarakat. Salah satu butir nawacita Presiden Republik Indonesia Joko Widodo adalah memperkuat karakter bangsa dan ingin melakukan gerakan nasional revolusi mental yang akan di terapkan di seluruh sendi kehidupan berbangsa dan bernegara termasuk didalam dunia pendidikan. Untuk menwujudkan pembentukan karakter bangsa sebagai salah satu gerakan nasional revolusi mental kementrian pendidikan dan kebudayaan menetapakan penguatan pendidikan karakter masuk dalam sistem pendidikan nasional. Penumbuhan karakter bangsa ingin dilaksankan secara masif dan sistematis.

Penguatan pendidikan karakter dilakasanakan dengan menerapkan nilai-nilai Pancasila dalam pendidikan karakter terutama melputi nilai-nilai religius, jujur, toleran, disiplin, bekerja keras, kreatif, mandiri, demokratis, rasa ingin tahu, semangat kebangsaan, cinta tanah air, menghargai prestasi, komunikatif, cinta damai, gemar membaca, peduli lingkungan, peduli sosial dan bertanggung jawab, yang merupakan nilai perwujudan dari nilai utama yaitu religuitas, nasionalisme, kemandirian, gotong royong dan integritas yang terintegrasi dalam kurikulum.

Upaya penguatan tersebut juga menjadi dasar dalam penerapan kurikulum 2013. Hal ini dapat dilihat pada penerapan kurikulum 2013 yang memberikan perubahan paradigma, dimana pada hasil akhir pembelajaran peserta didik tidak hanya menguasai pengetahuan tetapi juga menguasai sikap dan keterampilan. Sesuai dengan Standar Kompetensi Lulusan, sasaran pembelajaran mencakup pengembangan ranah sikap, pengetahuan, dan keterampilan yang dielaborasi untuk setiap satuan pendidikan. Hal tersebut ditegaskan dalam Permendikbud No. 20 Tahun 2016 yang menyatakan bahwa setiap lulusan satuan pendidikan dasar dan menengah memiliki kompetensi pada tiga dimensi yaitu sikap, pengetahuan, dan keterampilan.

SMPN 3 Bontomarannu merupakan salah satu sekolah yang berada di Kecamatan Bontomarannu Kabupaten Gowa yang telah menjalankan sistem pembelajaran kurikulum 2013. Sekolah sedang menjalankan program penguatan pendidikan karakter untuk memperkuat penanaman nilai karakter peserta didik baik lewat kegiatan intrakurikuler, kokurikuler dan ekstrakurikuler. Kegiatan intrakulikuler merupakan proses pembelajaran yang dilakukan secara terus menerus yang telah terjadwal sesuai dengan kalender akademik, serta menjadi tanggung jawab guru setiap mata pelajaran dengan tujuan untuk menumbuhkan kemampuan akademik peserta didik. Kegiatan kokurikuler misalnya guru memberikan tugas tambahan berupa pekerjaan rumah (PR) yang ada kaitannya dengan materi pembelajaran yang sedang dibahas. Kegiatan ektrakurikuler seperti Pramuka, PMR, Volly, Sepakbola bertujuan untuk mengambangkan minat dan bakat peserta didik.

Namun kenyataannya di SMPN 3 Bontomarannu pengimplementasian penguatan pendidikan karakter masih kurang optimal dikarenakan masih banyaknya peserta didik yang melanggar aturan sekolah misal beberapa pesera didik tidak mengikuti pembelajaran di kelas, terlambat ketika upacara bendera, tidak ikut pada saat melaksanakan jumat ibadah dan shalat berjamaah, tidak ikut kerja bakti dalam membersihkan sekolah. Berdasarkan hasil observasi yang telah dilakukan pada bulan September 2019 terdapat 47 peserta didik yang terlambat mengikuti upacara bendera, terdapat 11 peserta didik yang tidak mengikuti pembelajaran dan terdapat 2 orang peserta didik melakukan kasus perkelahian.

Berdasarkan Observasi awal maka dari itu peneliti mencoba mencari tahu bagaimana "Implementasi Program Penguatan Pendidikan 
Karakter di SMPN 3 Bontomarannu Kabupaten Gowa.

\section{TINJAUAN PUSTAKA}

\section{A. Tinjauan tentang PenguatanPendidikan Karakter}

\section{Pendidikan Karakter}

Pendidikan adalah usaha sadar dan terencana untuk menwujudkan suasana belajar dan proses pembelajaran agar peserta didik secara aktif mengembangkan potensi dirinya untuk memiliki kekuatan spiritual, keagamaan, pengendalian diri, kepribadian, kecerdasan, akhlak mulia, serta keterampilan yang diperlukan dirinya, masyarakat, bangsa dan negara. Ki Hajar Dewantara dalam Abu Ahmadi dan Nur Ukhbiyanti (1991: 69) mendefinisikan pendidikan sebagai tutunan segala kekuatan kodrat yang ada pada anak agar mereka kelak menjadi manusia dan anggota masyarakat yang dapat mencapai keselamatan dan kebahagiaan yang setinggi-tingginya.

Sementara itu, istilah karakter yang dalam bahasa inggris charakter, berasal dari istilah yunani, charakter dari kata charassei yang berarti membuat tajam atau membuat dalam. Karakter juga dapat berarti mengukir. Sifat utama ukiran dalah melekat kuat diatas benda yang diukir. Karena itu, Wardni dalam (Kurniawan 2017: 28) menyatakan bahwa "karakter adalah ciri khas seseorang dan karakter tidak dapat dilepaskan dari konteks sosial budaya karena karakter terbentuk dalam lingkungan sosial budaya tetentu". Pendidikan karakter adalah upaya yang dilakukan dengan sengaja untuk mengembangkan karakter yang baik (good Charcter) berlandaskan kebajikan kebajikan inti ( Core virtues) yang secara objektif baik bagi individu maupun masyarakat.

Menurut H. Tegu Sunaryo dalam (Kurniawan, 2017: 30) berpendapat bahwa pendidikan karakter menyangkut bakat (potensi dasar alami), harkat (derajat melalui penguasaan ilmu dan teknologi), dan martabat (harga diri melalui etika dan moral).

$$
\text { Menurut Zubaedi (2011:25), }
$$
pendidikan karakter adalah pendidikan budi pekerti plus, yang intinya merupakan program pengajaran yang bertujuan mengembangkan watak dan tabiat peserta didik dengan cara menghayati nilai-nilai dan keyakinan masyarakat sebagai kekuatan moral dalam hidupnya melalui kejujuran, dapat dipercaya, disiplin, dan kerja sama yang menekankan rana efektif (perasaan/ sikap) tanpa meninggalkan rana kognitif (berpikir rasional), dan ranah skill ( keterampilan, terampil mengolah data, mengeluarkan pendapat dan kerja sama.

\section{Nilai-nilai Pendidikan karakter}

Pendidikan karakter dilakukan melalui pendidikan nilai-nilai atau kebajikan yang menjadi nilai dasar karakter bangsa. Kebajikan yang menjadi atribut suatu karakter pada dasarnya adalah nilai. Menurut Pendidikan Nasional 18 nilai-nilai dalam pendidikan karakter adalah sebagai berikut : (a) Religius, (b) Jujur, (c) Toleransi, (d) Disiplin, (e) Kerja Keras, (f) Kreatif, (g) Mandiri, (h) Demokratis, (i) Rasa Ingin Tahu, (j) Semangat Kebangsaan, (k) Cinta tanah air, (l) Menghargai Prestasi, (m) Bersahabat/Komunikatif, (n) Cinta Damai, (o) Gemar Membaca, (p) Peduli Lingkungan, (q) Peduli Sosial, (r) Tanggung Jawab.

Delapan belas nilai untuk pendidikan karakter diatas merupakan perwujudan dari lima nilai utama yang saling berkaitan yaitu religiusitas, nasionalisme, kemandirian, gotong royong dan integritas yang terintegrasi dalam kurikulum.

\section{Tujuan Pendidikan Karakter}

Pada hakikatnya, tujuan pendidikan karakter tidak terlepas dari tujuan pendidikan nasional yang merupakan landasan konseptual filosofi pendidikan yang membebaskan dan mampu menyiapkan generasi masa depan untuk dapat bertahan hidup (survive) dan berhasil menghadapi tantangan-tantangan zamannya. Fungsi dan tujuan Pendidikan nasonal menurut undang-undang sistem pendidikan nasional No. 20 Tahun 2003 Pasal 3: "Pendidikan nasional berfungsi mengembangkan kemampuan dan membentuk watak serta peradaban bangsa yang bermartabat dalam rangka mencerdaskan kehidupan bangsa, bertujuan untuk perkembangannya potensi peserta didik agar menjadi manusia yang beriman dan bertakwa kepada tuhan yang maha esa, berakhlak mulia, sehat, berilmu, cakap, kreatif, mandiri dan menjadi warga negara yang demokratis serta bertanggung jawab."

4. Penguatan Pendidikan Karakter berdasarkan Permendikbud No 20 tahun 2018 
Penguatan pendidikan karakter merupakan program yang saat ini sedang dilakasanakan pemerintahkepada seluruh sekolah di Indonesia. Menurut Kemendikbud (2016:2) "Penguatan pendidikan karakter adalah program pendidikan di sekolah untuk memperkuat karakter siswa melalui harmonisasi olah hati, olah rasa, olah pikir dan olah raga dengan dukungan perlibatan publik dan kerja sama antara sekolah, keluarga, dan masyarakat yang merupakan bagian dari Gerakan Nasional Revolusi Mental (GNRM)" Menurut Bennert (Wibowo, 2012:53) menyatakan bahwa sekolah memiliki peran yang sangat urgen dalam pendidikan karakter seorang peserta didik.menurut Sriwilujeng (2017: 4) mengemukakan bahwa: "Penguatan pendidikan karakter (PPK) merupakan proses pembentukan, transformasi, dan pengambangan potensi peserta didik agar memiliki pikiran yang baik, hati yang baik, dan perilaku yang baik; sesuai dengan falsafa pancasila sebagaipedoman hidup bangsa Indonesia. PPK juga telah menjadi perhatian berbagai negara dalam rangka mempersiapkan generasi yang berkualitas bukan hanya untuk kepentingan individu, tetapi juga untuk masyarakat secara keseluruhan."

Menurut Sriwilujengg (2017: 7) penguatan pendidikan karakter merujuk pada lima nilai utama yang meliputi;

a. Religius(Mencerminkan) keberimanan terhadap Tuhan Yang Maha Esa)

b. Nasionalis(Menempatkan kepentingan bangsa dan negara diatas kepentingan diri dan kelompoknya).

c. Mandiri (Tidak bergantung pada orang lain dalam menggunakan tenaga, pikiran, waktu untuk merealisasikan harapan, dan cita-cita).

d. Gotong royong(Mencerminkan tindakan menghargai semangat kerja sama dan bahu membahu menyelesaikan persoalan bersama).

e. Integritas (Upaya menjadikan dirinya sebagai seorang yang selalu dapat dipercaya dalam perkataan, tindakan dan pekerjaan).

Strategi implementasi penguatan pendidikan karakter disatuan pendidikan dapat dilakukan melalui kegiatan berikut ini (Sriwilujeng, 2017:7) :
1. Kegitan intrakurikuler adalah kegiatan pembelajaran yang dilakukan oleh sekolah secara teratur dan terjadwal, yang wajib dikuti oleh setiap peserta didik. Program intrakurikuler berisi berbagai kegiatan untuk meningkatkan Standar Kompetensi Lulusan melalui Kompetensi Dasar yang harus dimiliki peserta didik yang dilaksanakan sekolah secara terus menerus setiap hari sesuai dengan kalender akademik.

2. Kegiatan kokurikuler adalah kegiatan pembelajaran yang terkait dan menunjang kegiatan intrakurikuler, yang dilaksanakan diluar jadwal intrakurikuler dengan maksud agar peserta didik lebih memahami dan memperdalam materi intrakurikuler. Kegiatan kokurikuler dapat berupa penugasan, proyek, ataupun kegiatan pembelajaran lainya yang berhubungan dengan materi intrakurikuler yang harus diselesaikan oleh peserta didik.

3. Kegiatan ekstrakurikuler adalah kegiatan pengembangan karakter yang dilaksanakan diluar jam pembelajaran (intrakurikuler). Aktivitas ekstrakurikuler berfungsi menyalurkan dan mengembangkan minat dan bakat peserta didik dengan memperhatikan karakteristik peserta didik, kearifan lokal, dan daya dukung yang tersedia.

\section{METODE}

Dalam penelitian ini, peneliti menggunakan metode penelitian deskriptif kualitatif.Deskripsi fokus penelitian mengenai beberapa aspek yaitu (1) Pengimplementasian program penguatan pendidikan karakter melalui kegiatan intrakurikuler, kokurikuler, ekstrakurikuler. Penguatan nilai karakter merujuk pada lima nilai utama yaitu religius, nasionalis, mandiri, gotong royong, integritas, (2) Faktor pendukung merupakan semua hal yang ikut memberikan dukungan positif terhadap pelaksanaan program penguatan pendidikan karakter pada SMPN 3 Bontomarannu Kabupaten Gowa, (3) Faktor penghambat merupakan semua hal yang dianggap kendala dalam pelaksanaan program 
penguatan pendidikan karakter pada SMPN 3 Bontomarannu Kabupaten Gowa.

Lokasi penelitian ini dilakukan di SMPN 3 Bontomarannu Kabupaten Gowa,

Teknik pengumpulan data yang digunakan peneliti: (a) Observasi; (b) Wawancara; (c) Dokumentasi.

Dalam proses analisis data terdapat komponen-komponen utama yang harus dipahami. Komponen tersebut adalah pengumpulan data, reduksi data, sajian data, penarikan kesimpulan atau verifikasi.

\section{HASIL DAN PEMBAHASAN}

\section{Implementasi Program Penguatan Pendidikan Karakter di SMPN 3 Bontomarannu Kabupaten Gowa}

Implementasi penguatan pendidikan karakter di sekolah sangat berperan dalam memperkuat karakter peserta didik di SMPN 3 Bontomarannu. Hal ini sesuai dengan tujuan penguatan pendidikan karakter yang di singkat PPK yaitu untuk memperkuat karakter peserta didik melalui harmonisasi olah hati, olah rasa, olah pikir dan olah raga. Dengan dukungan pelibatan publik dan kerjasama antar sekolah, keluarga dan masyarakat. Sebagaimana yang di sampaikan Bapak Mahalang selaku kepala SMPN 3 Bontomarannu bahwa: "Berbicara mengenai PPK tentunya untuk membentuk karakter peserta didik makanya anak-anak harus kita bekali nilai-nilai moral, spiritual, agama, serta ilmu, guna menghadapi tantangan dimasa yang akan datang, Sebagaimana arahan dari pemerintah dalam membentuk karakter peserta didik melalui proses pembelajaran dalam kelas, tugas tambahan diluar kelas dan kegiatankegiatan ekstrakulikuler seperti Pramuka dan PMR serta ektrakulikulerlainnya sesuai minat dan bakat anak-anak. Dalam gerakan PPK yang berfokus pada struktur kurikulum, antara lain kegiatan pembentukan karakter yang terintegrasi dalam pembelajaran (intrakurikuler), Kokulikuler dan ektrakurikuler.

a. Implementasi Penguatan Pendidikan Karakter di dalam Kelas Melalui Kegiatan Intrakulikuler

Pelaksanaanpenguatan pendidikan karakter itu terintegrasi nilai-nilai PPK ke dalam proses pembelajaran dalam setiap mata pelajaran. Pembelajaran yang mengintegrasikan nilai-nilai utama karakter dimaksud untuk menumbuhkan dan menguatkan pengetahuan,menanamkan kesadaran, dan memperaktikkan nilai-nilai utama PPK. Selanjutnya di ungkapkan pula oleh Ibu Syarifa Rosdiana selaku guru bahasa inggris sekaligus wakasek bagian kurikulum mengatakan bahwa: "dalam penerapan PPK terintegrasi melalui pembelajaran guru-guru mata pelajaran membuat silabus, RPP yang memuat fokus penguatan karakter dengan memilih metode pembelajaran dan pengelolaan kelas sampai pada tahap evaluasi terhadap keseluruhan proses pembelajaran selanjutnya dalam penerapannya itu dikembalikan kepada guru masing-masing untuk melaksanakan yang telah direncanakan."

Oleh karena itu, untuk mengetahui penerapan PPK dilihat dari berbagai mata pelajaran yaitu (1) Pendidikan Agama Islam, (2) Pendidikan Pancasila dan Kewarganegaraan, (3) Pendidikan Jasmani Olaraga dan Kesehatan, (4) Bahasa Indonesia, (5) Bahasa Inggris, (6) Matematika, (7) Ilmu Pengetahuan Alam, (8) Ilmu Pengetahuan Sosial, (9) Seni Budaya, (10) Prakarya, (11) Bahasa Daerah, (12) Bimbingan Konseling.

b. Implementasi Penguatan Pendidikan Karakter di Luar Kelas melalui Kegiatan Kokulikuler

Kegiatan Kokulikuler merupakan kegiatan pembelajaran yang terkait dan menunjang kegiatan intrakulikuler, yang dilaksanakan diluar jadwal intrakulikuler dengan maksud agar peserta didik lebih memahami dam memperdalam materi intrakulikuler. Sebagaimana yang disampaikan oleh Ibu Syarifa Rosdiana sebagai wakasek kurikulum mengatakan bahwa: "materi pembelajaran di dalam kelas selalu diimbangi dengan pemberian kegiatan kokulikuler, biasanya guru-guru mata pelajaran memberikan tugas kepada peserta didik yang sesuai dengan kompetensi dasar yang guru berikan di dalam kelas, baik untuk proyek kelompok ataupun individu kepada peserta, supaya materi yang di ajarkan di dalam kelas lebih diserap oleh 
siswa yang kemudian diaplikasikan kedalam tugas yang guru-guru berikan."

c. Implementasi Penguatan Pendidikan Karakter di Luar Kelas melalui Kegiatan Ekstrakulikuler

Ekstrakulikuler merupakan bagian atau kegiatan yang diselenggarakan diluar jam pelajaran wajib , untuk memperdalam dan memperluas pengetahuan siswa yang berhubungan dengan materi yang dipilih. Adapun ekstrakulikuler yang diterapkan dilingkungan sekolah SMPN 3 Bontomarannu yaitu ekskulikuler Pramuka, Palang Merah Remaja (PMR), Rohani Islam (Rohis), Sepak Bola, Bola Volly, dan Seni Tari, sesuai dengan pernyataan Bapak Mahlang selaku kepala SMPN 3 Bopntomarannu: "di sekolah ini, peserta didik tidak hanya dibekali ilmu pengetahuan tetapi juga dikembangkan minat dan bakatnya melalui kegiatan ekstrakulikuler, mereka bebas memilih kegiatan ekskul yang mereka mau semuai minat dan bakatnya"

Bentuk penerapan nilai utama penguatan pendidikan karakter di SMPN 3 Bontomarannu:

\section{Religius}

Karakter religius yang dilakukan yaitu : berdoa sebelum dan sesudah pembelajaran, mengikuti ektrakurikuler rohis, melaksanakan kegiatan ibadah seperti jumat'at Ibadah, dan shalat zduhur berjama'ah.

\section{Nasionalis}

Karakter nasionalis yang di lakukan yaitu: mengikuti upacara bendera setiap hari senin, serta upacara hari besar yang diadakan disekolah, menyanyikan lagu-lagu nasional sebelum pembelajaran, mengikuti kegiatan ektrakurikuler Pramuka dan PMR

\section{Mandiri}

Karakter mandiri yang di lakukan yaitu: bertanggung jawab atas perbuatan yandilakukan, percayadiri ketika mengeluarkan pendapat.

\section{Gotongroyong}

Karakter gotong royong yang dilakukan yaitu: bekerja bakti dalam memelihara dan keindahan sekolah, memberikan bantuan moril maupun materil kepada temannya yang terkena musibah, membersihkan ruang kelas dan taman diluar kelas sesuai jadwal piket.

\section{Integritas}

Karakter integritas yang dilakukan yaitu : mentaati tata tertib sekolah, mengembalikan buku pembelajaran di perpustakaan setelah pembelajaran selesai sesuai dengan jumlah buku yang dipinjam, dan mengerjakan tugas dari guru dengan tepat waktu.

\section{Faktor Pendukung dalam Implementasi Program Pendidikan Karakter di SMPN 3 Bontomarannu Kabupaten Gowa}

a. Kompetensi Guru.

Dalam proses pembelajaran, guru tidak hanya menjalankan fungsi alih ilmu pengetahuan (transfer of knowledge) tapi juga berfungsi untuk menanamkan nilai (value) serta membangun karakter (Character Building) peserta didik secara berkelanjutan. Sebagaimana yang disampaikan oleh Pak Bakri selaku guru PPKn mengatakan bahwa:"kita sebagai guru tidak hanya memberikan teori pembelajaran di dalam kelas, tapi lebih dari itu karena yang paling penting adalah mendidik peserta didk, memberikan pemahaman nilai-nilai karakter pada mereka".

b. Kerja sama wali peserta didik

Wali yang dimaksud dalam hal ini adalah peran orang tua yang sangat membantu anak untuk menumbuhkan kesadaran agar mengikuti pembiasaan-pembiasaan yang diterapkan di sekolah dengan baik.

c. Kurikulum yang sudah baik Kurikulum harus mampu menyeimbangkan aspek akademik dan karakter sehingga mampu mewujudkan lingkungan sekolah yang aman, nyaman, dan menyenangkan. Sebagaimana yang disampaikan oleh ibu Syarifa Rosdiana selaku waka Kurikulum mengatakan bahwa:"dalam pelaksanaan kurikulum 2013 memiliki muatan PPK sehingga dalam pembuatan rencana pembelajaran sudah diintegrasikan dengan PPK."

\section{d. Pengawasan Kepala Sekolah}

Kepala sekolah memiliki peranan penting dalam proses pendidikan karakter di sekolah. Selain pejabat struktural dan administratif di sekolah, kepala sekolah juga berfungsi sebagai supervisor pengawasan dan 
bimbingan untuk dinamika kelompok guru, assisten laboratorium, administrator dan staf sekolah. Berdasarkan hasil wawancara yang dilakukan bersama Bapak Mahalang selaku kepala SMPN 3 Bontomarannu mengatakan bahwa: "setiap sebulan sekali kita mengadakan evaluasi rutin terkait progres dan permasalahan yang dihadapi oleh bapak ibu guru di dalam kelas, ataupun pelaporan dari masng-masing wali kelas."

\section{Faktor Penghambat dalam Implementasi Program Pendidikan Karakter di SMPN 3 Bontomarannu Kabupaten Gowa}

a. Sarana dan prasarana

Sarana dan prasarana sekolah yang kurang memadai menjadi salah satu faktor penghambat dalam pelaksanaan penguatan pendidikan karakter melalui kegiatan pembiasaan di sekolah dalam pelaksanaan jumat ibadah sebagian siswa berada diluar mushallah di karenakan musallah tidak mampu menampung semua peserta didik, kemudian dalam penggunaan Laboratorium IPA tidak efektif karena beralih fungsi menjadi ruang kelas.

\section{b. Kualifikasi akademik yang tidak sesuai kualifikasi akademik merupakan} kemampuan yang dimiliki pendidik yang sesuai dengan latar belakang keilmuannya. Namun ada beberapa matapelajaran yang diampuh yang tidak sesuai dengan latar belakang keilmuannya seperti bahasa daerah yang diampuh oleh guru IPA, seni budaya yang diampuh oleh guru Bahasa Inggris, dan prakarya yang di ampuh oleh guru Pendidikan Agama Islam.

c. Karakter Peserta Didik yang berbeda-beda tentu setiap peserta didik memiliki sifat yang berbeda-beda, ada yang mudah diatur, ada juga yang sangat sulit diatur.

d. Kedisiplinan peserta didik masih rendah kedisiplinan peserta didik masih rendah dilihat dari peserta didik yang sering datang terlambat datang disekolah, tidak mengikuti upacara dan melanggar tatatertib sekolah.

\section{Pembahasan}

\section{Implementasi Program Penguatan Pendidikan Karakter di SMPN 3 Bontomarannu Kabupaten Gowa}

a. Implementasi Penguatan Pendidikan Karakter di dalam Kelas Melalui Kegiatan Intrakulikuler

Dalam kegiatan intrakurikuler pelaksanaan penguatan pendidikan karakter itu terintegrasi nilai-nilai PPK ke dalam proses pembelajaran dalam setiap mata pelajaran. Pembelajaran yang mengintegrasikan nilai-nilai utama karakter dimaksud untuk menumbuhkan dan menguatkan pengetahuan, menanamkan kesadaran, dan memperaktikkan nilai-nilai utama PPK yaitu religius, nasionalis, mandiri, gotong royong, dan integritas.

b. Implementasi Penguatan Pendidikan Karakter di luar Kelas melalui Kegiatan Kokulikuler

Guru sebagai fasilitator peserta didikdalam kegiatan kokulikuler berperan untuk merancang, memfasilitasi, menawarkan, menyediakan, ataupun membantu sumbersumber pembelajaran PPK bagi peserta didik. Peran yang dilakukan dapat berupa penyediaan buku-buku literatur yang relevan dengan PP, pemberian tugas makalah yang bersumber dari jurnal-jurnal ilmiah, serta penugasan kepada peserta didik untuk mebaca, menyampaikan materi, mendidkusikan, mempraktikkan apa yang diperoleh dari sumber-sumber yang disedikana oleh guru sebagai fasilitator.

c. Implementasi Penguatan Pendidikan Karakter di luar Kelas melalui Kegiatan Ekstrakulikuler

Pesrta didik merupakan individu- individu yang memiliki karakteristik yang berbeda-beda satu sama lan, sehingga dapat dipastikan adanya minat dan bakat yang berbeda pula. Dengan adanya hal tersebut, guru berperan sebagai fasilitator untuk mewadahi, menyediakan kegiatan PPK sesuai karakteristik, minat dan bakat peserta didik salah satu caranya adalah dengan menyiapkan kegatan ekstrakulikuler.

Bentuk penerapan nilai utama penguatan pendidikan karakter di SMPN 3 Bontomarannu:

1) Religius

Nilai religius ini mencerminkan keberimanan kepada Tuhan Yang Maha Esa 
yang siwujudkan dalam perilaku melaksanakan ajaran agama dan kepercayaan yang dianut, menghargai perbedaan agama, menjunjung sikap toleran terhadap pelaksanaan ibadah adama dan kepercayaan lain, hidup rukun dan damai dengan pemeluk agama lain. Nilai karakter religius meliputi hungan individu dengan Tuhan, individu dengan sesama, dan individu dengan alam semesta (lingkungan).

2) Nasionalis

Nilai karakter nasionalis mencerminkan cara berpikir, bersikap, dan berbuat yang menujukkan kesetiaan, kepedulian, dan penghargaan yang tinggi terhadap bahsa, lingkungan fisik, sosial, budaya, ekonomi, politik bangsa, menempatkan kepentingan bangsa dan negara diatas kepentingan diri dan kelompok.

3) Mandiri

$$
\text { Nilai karakter mandiri }
$$

mencerminkan sikap dan perilaku tidak bergantung pada orang lain dan mempergubakan segala tenaga, pikiran, waktu untuk merealisasikan harapan, mimpi, dan cita-cita.

4) Gotong Royong

Nilai karakter gotong royong mencerminkan tindakan menghargai semangat kerjasama dan bahu membahu menyelesaikan persoalan bersama, menjalin komunikasi dan persahabatan, memberi bantuan,/pertolongan pada orang-orang yang membutuhkan.

5) Integritas

Nilai karakter integritas mencerminkan nilai yang medasari perilaku yang didasarkan pada upaya menjadikan dirinya sebagai orang yang selalu dapat dipercaya dalam perkataan, perbuatan, dan pekerjaan, memiliki komitmen da kesetiaan pada nilai-nilai kemanusiaan dan moral

\section{Faktor Pendukung dalam Implementasi Program Pendidikan Karakter di SMPN 3 Bontomarannu Kabupaten Gowa}

a. Kompetensi Guru
Peran guru sangat berpengaruh dalam proses pendidikan kedepannya, dalam proses pembelajaran, guru tidak hanya menjalankan fungsi alih ilmu pengetahuan (transfer of knowledge) tapi juga berfungsi untuk menanamkan nilai (value) serta membangun karakter (Character Building) peserta didik secara berkelanjutan.

b. Kerjasama wali peserta didik

Wali/ orangtua peserta didik sangat mendukung anak-anaknya dalam pengembangan karakter di sekolah dan memantau perkembangan kemanpuan akademik anaknya serta memantau perkembangan kepribadian yang mencakup sikap, moral dan tingkah laku anaknya. Hal ini dilakukan orang tua dengan berkomunikasi dengan wali kelas untuk mengetahui perkembangan anaknya di sekolah

c. Kurikulum yang sudah baik

Penerapan penguatan pendidikakan karakter, di samping dipengaruhi oleh guru yang bekualitas, juga sangat di tentukan kurikulumyang digunakan. Kurikulum yang baik, terbuka, dinamis dan dapat mengakomodasi keterampilan global dan didukung oleh pihak sekolah serta kurikulum membantu siswa dalam mencerna mata pelajaran untuk menumbuhkan sikap saling menghormati, toleransi, harmoni dalam kehidupa yang penuh kedamaian. Guru harus senantiasa di dorong untuk membawakan pelajaran dengan menyenangkan dan lebih hidup. Pengembangan nilai-nilai pendidikan karakter bangsa diintegrasikan dalam setiap pokok bahasan dalam setiap mata pelajaran. Nilai-nilai tersebut dicantumkan dalam silabus dan RPP.

\section{d. Pengawasan Kepala Sekolah}

Strategi pengembangan pendidikan karakter dingangun melalui gaya kepemimpinan demokrasi dengan menstimulasi bawahannya untuk bekerja sama dalam mencapai tujuan bersama. Mengadakan rapat bulanan, atau rapat sesuai dengan situasi dan kondisi yang diperlukan untuk memberi pengarahan dengan mengedepankan musyawarah dalam mengambil keputusan demi melahirkan karakter yang baik di lingkungan sekolah. 


\section{Faktor Penghambat dalam Implementasi Program Pendidikan Karakter di SMPN 3 Bontomarannu Kabupaten Gowa}

\section{a. Sarana dan Prasarana}

Sarana dan prasarana merupakan salah satu dalam pemenuhan standar pendidikan nasional. Kurang memadainya fasilitas seperti mushollah yang tidak mampu menampung peserta didik ketika pelaksanaan jum'at ibadah, fasilitas laboratorium yang belum lengkap serta beralih fungsi menjadi ruang kelas.

\section{b. Kulifikasi akademik yang tidak sesuai}

$$
\text { Kualifikasi akademik yakni }
$$

kemampuan yang dimiliki oleh seorang guru dalam pembelajaran peserta didiknya. Namun di SMPN 3 Bontomarannu terdapat guru yang mengajar tidak sesuai dengan latar belakang keilmuannya, seperti guru bahasa daerah yang latarbelakang keilmuannya IPA, prakarya dan seni budaya yang latar belakang keilmuannya Bahasa inggris.

c. Karakter peserta didik yang berbedabeda

Ada beragam lingkungan yang diinternalisasikan ke dalam diri seseorang yang mengakibatkan ia melakukan proses pilihan dalam mewujudkan karakter dan perilaku. Lingkungan sekitar yang baik akan memberikan nilai-nilai baik pada diri seseorang, sehingga akan mewujudkan karakter dan perilaku yang baik pula selaras dengan lingkungan yang dihadapi. Pengaruh lingkungan luar memang ada dan berpengaruh, namun sekolah adalah sentral utama pembentukan watak anak.

Proses pendidikan di sekolah lebih besar porsinya dalam membina tidak hanya akal tapi hati dan akhlaq anak.Pendidkan karakter dapat menjadi sebuah usaha untuk menanamkan, mengarahkan, membentuk, dan mengembangkan karakter peserta didik.

d. Kedisiplinan peserta didik masih rendah

Kedisiplinan dalam proses pendidikan sangat diperlukan karena bukan hanya untuk menjaga kondisi suasana pembelajaran berjalan dengan lancar, tertapi juga untuk menciptakan pribadi yang kuat bagi peserta didik. Namun kedisiplinan peserta didik di SMPN 3 Bontomarannu masi rendah dilihat dari peserta didik yang sering datang terlambat datang disekolah, tidak mengikuti upacara dan melanggar tatatertib sekolah.

\section{SIMPULAN DAN SARAN}

Berdasarkan penelitian yang telah dilakukan di SMPN 3 Bontomarannu Dalam mengimplementasikan penerapan pengutan pendidikan karakter dapat ditarik kesimpulan bahwa: (1) Implementasi Penguatan Pendidikan Karakter di SMPN 3 Bontomarannu sudah berjalan namun pelaksanaannya belum maksimal; (2) Faktor pendukung dalam mengimplementasikan penguatan pendidikan karakter di SMPN 3 Bontomarannu adalah kompetensi guru, kerjasama yang baik dari wali peserta didik, kurikulum sekolah yang sudah baik, pengawasan intens dari kepala sekolah; (3) Faktor penghambat dalam mengimplementasikan penguatan pendidikan karakter di SMPN 3 Bontomarannu adalah Sarana dan Prasarana, kualifikasi akademik guru yang tidak sesuai dengan mata pelajaran yang diajarkan, adanya karakter yang berbeda-beda pada peserta didik, kedisiplinan peserta didik yang masih rendah.

Adapun saran dalam penelitian ini adalah: (1) Bagi Kepala SMPN 3 Bontomarannu, untuk selalu meningkatkan kualitas pendidikan dan menambah kuantitas pendidik dan tenaga kependidikan, serta melengkapi memperbanyak fasilitas untuk mendukung berjalannya kegiatan di sekolah; (2) Bagi tenaga pendidik di SMPN 3 Bontomarannu, untuk menanamkan kepada peserta didik perilaku yang baik dengan cara terlebih dahulu menjadi fasilitator sekaligus role model untuk peserta didik; (3) Bagi peserta didik, sebagai genarasi bangsa hendaknya membangun dan membiasakan diri untuk melakukan suatu kebaikan dan membentuk karalter yang baik dalam diri.

\section{DAFTAR RUJUKAN}

Abu Ahmadi dan Nur Ukhbiyanti.1991.Ilmu Pendidikan Islam. Jakarta: Rineka Cipta.

Agus Wibowo.2012.Pendidikan Karakter: Strategi Membangun Karakter BangsaPerperadaban. Yogyakarta: Pustaka Pelajar.

Dharma Kesuma.2013. Pendidikan Karakter: Kajian Teori dan Praktik di Sekolah. Bandung: PT. Remaja Rosdakarya. 
Huberman.2007. Analisis Data Kualitatif. Jakarta: Universitas Indonesia Press

Kurniawan Syamsul.2017. Pendidikan

Karakter:Konsepsi dan Implementasi secara terpadu dilingkungan keluarga, Sekolah, Perguruan Tinggi, Masyarakat.Yogyakarta. Ar-Ruzz Media.

Kemendikbud. 2018. Infografis Gerakan Penguatan Pendidikan Karakter (PPK).

Imam Gunawan. 2013. Metode Penelitian Kualitatif, Teori Dan Praktik. Jakarta: PT Bumi Aksara.

Tohirim. 2012. Metode Penelitian Kualitatif Dalam Pendidikan Dan Bimbingan Konseling, Pendekatan Praktis Untuk Peneliti Pemula Dan Dilengkapi Dengan Contoh Transkrip Hasil Wawancara Serta Model Penyajian Data. Jakarta. Raja Grafindo Persada

H.Mangun Budiyanto.2010. Ilmu Pendidikan Islam. Yogyakarta: Griya Santri.

Sriwilujeng Dyah. 2017. Panduan Implementasi Penguatan Pendidikan Karakter. Jakarta: Erlingga.

Zubaedi. 2011. Desain Pendidikan Karakter. Jakarta: Prenadamedia Group.

Undang-Undang Nomor 20 Tahun 2003 tantang Sistem Pendidikan Nasional

Peraturan Menteri Pendidikan dan Kebudayaan Nomor 20 Tahun 2018 tentang Penguatan Pendidikan Karakter Pada Satuan Pendidikan Formal. 